\title{
An infrared microspectroscopic study of plasters and pigments from the Neolithic site of Bestansur, Iraq
}

Article

Accepted Version

Creative Commons: Attribution-Noncommercial-No Derivative Works 4.0

Godleman, J., Almond, M. J. and Matthews, W. (2016) An infrared microspectroscopic study of plasters and pigments from the Neolithic site of Bestansur, Iraq. Journal of Archaeological Science: Reports, 7. pp. 195-204. ISSN 2352409X doi: https://doi.org/10.1016/j.jasrep.2016.04.013 Available at https://centaur.reading.ac.uk/68091/

It is advisable to refer to the publisher's version if you intend to cite from the work. See Guidance on citing.

To link to this article DOI: http://dx.doi.org/10.1016/j.jasrep.2016.04.013

Publisher: Elsevier

All outputs in CentAUR are protected by Intellectual Property Rights law, including copyright law. Copyright and IPR is retained by the creators or other copyright holders. Terms and conditions for use of this material are defined in the End User Agreement.

www.reading.ac.uk/centaur 
Central Archive at the University of Reading

Reading's research outputs online 


\title{
An Infrared Microspectroscopic Study of Plasters and Pigments from the Neolithic site of Bestansur, Iraq
}

\author{
Jessica Godleman ${ }^{\mathrm{a}}$, Matthew J. Almond ${ }^{\mathrm{a}}$ and Wendy Matthews ${ }^{\mathrm{b}}$ \\ aDepartment of Chemistry, University of Reading, Whiteknights, Reading RG6 6AD; 'bepartment of \\ Archaeology, University of Reading, Whiteknights, Reading RG6 6AA.
}

\begin{abstract}
Infrared (IR) Spectroscopy and microspectroscopy ( $\mu$-IR) supported by Environmental Scanning Electron Microscope - Energy Dispersive X-Ray analysis (ESEM-EDX) has been utilised to investigate the technology and use of multi-coloured architectural plasters and pigments by Neolithic communities at the archaeological site of Bestansur, Iraq, c. 7,600 BC. Sub-samples of architectural materials and pigments were analysed using IR spectroscopy and fragile samples and thin sections were analysed using $\mu$-IR and ESEM-EDX to determine the mineralogical and elemental composition of individual components and layers and the history of construction and use of three large rectilinear buildings.

In addition, experimental investigations were undertaken into the application of IR to study of the firing of calcium carbonate and of clays to investigate if this technique was able to detect evidence of fired-lime materials and of reddening of building materials by fire. Whilst the IR analysis alone was not able to characterise the plasters and pigments, when combined with ESEM-EDX the minerals responsible for pigmentation in the samples were clearly identified. The green clay was determined to be local celadonite-bearing marine clays. The red pigment was found to contain iron, most likely in the form of hematite. The black pigment contained manganese and iron, likely to be present as manganese dioxide and magnetite. The investigations of firing indicate that a hard white exterior may come from fired-lime while a reddish silty clay wall surface had probably not been subject to high-temperature burning.
\end{abstract}

Analysis of a series of wall plasters and pigments from Building 8 (pre-7,600 BC) revealed experiment and development in technologies and materials throughout the occupation of the building, which in the final sequence resemble those from significantly later level at the site of Çatalhöyük, Turkey (c. 7,000 BC).

\section{Introduction}

Micro-analyses have been widely applied in studies of historic and Classical building materials and art [1-5] and are increasingly being applied to the study of earlier archaeological building materials and pigments [6-9] although there is scope for much wider application to these [10]. The great strengths of micro-analyses of intact samples are that they enable integrated high-resolution characterisation of the microstructure, composition and sequence of specific architectural components and materials as well as post-depositional alterations and features [11]. This data is vital to examination of the source materials and manufacture of architectural materials as well as studies of their value and significance according to where they were obtained from, the skill level required to produce them, and how spatially and temporally they were placed within a building or settlement to create particular places and settings for social, cultural and political interactions. The aim in this paper is to apply IR and ESEM-EDX analyses to examine the composition, technology and use of architectural materials in one of the heartlands of early built environments and agriculture, the Zagros region, at the site of Bestansur, Iraq, c. $7,660 \mathrm{BC}$.

Some of the earliest architecture in the world was constructed across southwest Asia, from Iran to Turkey from c. 12,000-10,000 $\mathrm{BC}$, during the transition from mobile hunting-gathering to more sedentary agriculture in the Neolithic. The earliest buildings were circular and constructed from stone and mud or a combination of both, depending in part on local resources. From c. 8,500-7,500 BC there was a major shift in building from circular to rectilinear architectural structures across this region, suggesting considerable knowledge transfer in architectural technology as well as early domesticated plants, animals and other material artefacts [12].The Zagros mountain chain and foothills of Iran and Iraq were one of the regions where wild species that were later domesticated naturally occurred in the Early Holocene, notably wild goat and barley, and provided a sustainable basis for more year round settlement [12]. Although some of the earliest scientific investigations into the origins 
of agriculture and sedentary communities architecture were undertaken in the Zagros piedmont and highlands in Iran and Iraq in the 1960s-70s [13-15], it is only recently that the importance of this region in these major transformations to more sedentary agricultural lifeways has been re-emphasised due to renewed excavations and fieldwork [16].

The aim of one of these projects; the Central Zagros Archaeological Project (CZAP) is to investigate early Neolithic resource management and sedentism at four sites in the Zagros to study local and regional variation in strategies and interaction between piedmont and highland zones [17]. This major project is co-directed by the University of Reading, the Department of Antiquities and Heritage Sulaimaniyah- Iran's Cultural Heritage Handicraft and Tourist Organisation and Bu Ali Sina University. The four Neolithic sites investigated span c. 9,800- 6,000 BC, and comprise Bestansur and Shimshara in piedmont zone in Iraq and Sheikh-e-Abad and Jani in highland Iran. The research in this paper focuses upon samples of architectural materials and pigments from Bestansur, c. 7,660 cal BC - a site which has yielded intact Neolithic objects across an area of at least $100 \times 50$ $\mathrm{m}$ [18]. Five seasons of excavation have been undertaken at this site and a map showing the location of trenches is given in Figure 2. The samples whose analysis is described in this paper were all taken from two trenches (Trenches 1 and 10, Figure 2).

Those from Trench 10 were selected from two large buildings with plastered walls, pigment and paint- Building 5 and Building 8 (see Figure 6). Building 8 has been dated to pre- 7600 BC while Building 5 was constructed on top of Building 8 and is dated to c. $7600 \mathrm{BC}$. The older Building 8 was constructed from boat-shaped mudbricks in walls coated with multiple layers of green, grey, brown and white plasters and washes and red pigmented wall painting in decoration. The later stages of decoration in Building 8 are not dissimilar to those seen at the more recent, internationally-renowned World Heritage site of Çatalhöyük in Turkey. The later Building 5 was constructed from rammed earth (pisé) architecture with more minimal plastering and decoration although fragments of red pigment and wall-painting have been found. More than 28 humans were buried, largely below the floors in a large room of this building labelled as Space 50 (Figure 6).

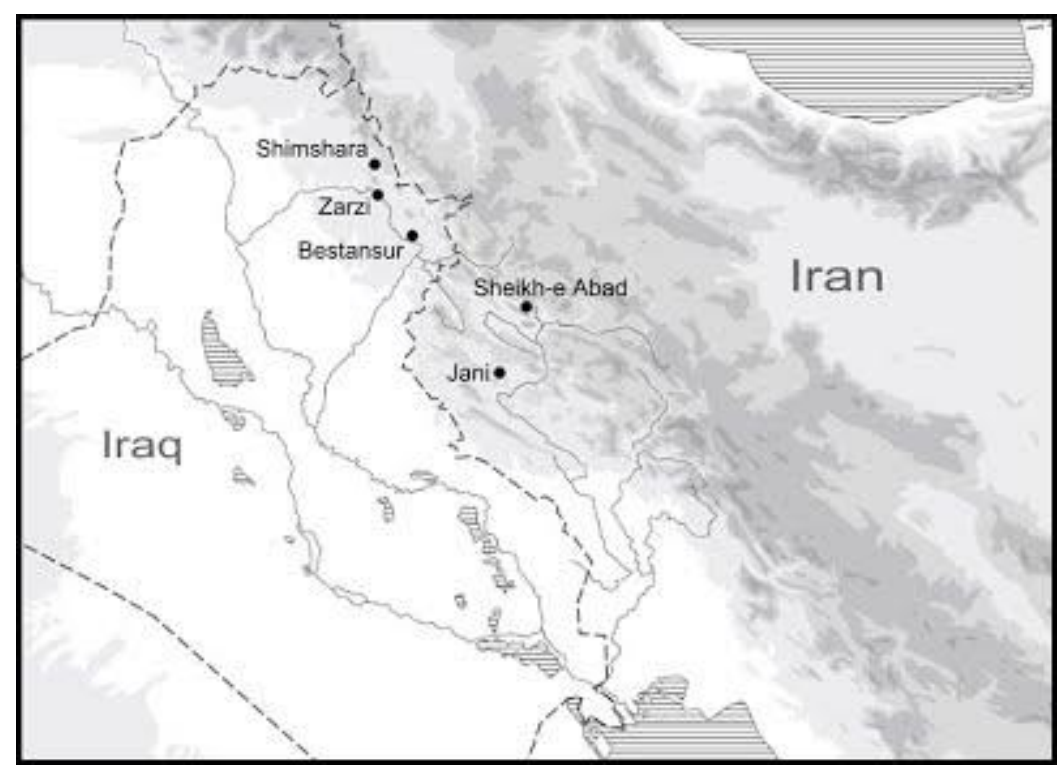

Figure 1-Location of sites being investigated within the Central Zagros Archaeological Project (CZAP). 


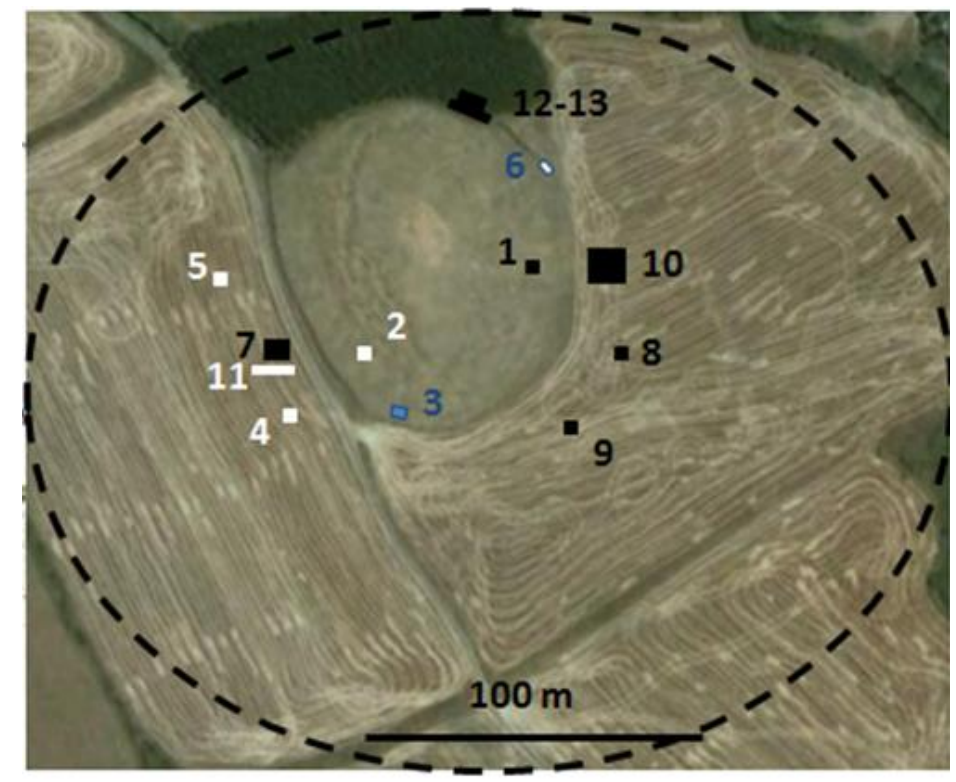

Figure 2- Aerial photograph of the mound at Bestansur, Iraq showing the position of trenches. The samples whose analysis is described in this paper were selected from Trenches 1 and 10.

The aim of the research described in this paper was to answer some specific questions concerning composition and use of plasters and pigments from these three buildings using infrared microspectroscopy supported by environmental scanning electron microscopy energy dispersive X-ray analysis (ESEM-EDX) where appropriate. The specific questions to be addressed were as follows.

\section{Trench 1. Building 2:}

i. Can evidence be found that clays found in walls of buildings in this trench have been heated e.g. by burning?

Trench 10. Building 5:

i. Is there any evidence that the hard whitish plasters at the front entrance of the building were made from fired lime i.e. $\mathrm{CaCO}_{3}$ which has been heated to produce $\mathrm{CaO}$ ? Fired-lime production requires considerable quantities of fuel and is thereby expensive to produce and requires considerable skilllevel [11].

ii. Is the red pigment found in this building from red ochre which occurs more locally in limestone regions or from cinnabar which is more exotic and known to occur in the north-west Zagros?

iii. What is the chemical nature of a black pigment/material found in a human skull? I sit an applied pigment or due to post-depositional processes?

\section{Building 8:}

i. What is the composition of the multiple layers of green, grey, brown and white plasters applied to the southern face of Wall 56 in this building?

ii. What is the nature of a red pigmented paint applied to the southern face of Wall 56 late in the history of this building?

A summary of the samples analysed and the methods used to investigate them is given in Table $\mathbf{1}$.

Table 1- Summary of samples analysed.

\begin{tabular}{|l|l|l|l|l|l|}
\hline Sample No. & Trench & Location & Sample type & Description & Analysis \\
\hline
\end{tabular}




\begin{tabular}{|c|c|c|c|c|c|}
\hline SA542 & 1 & $\begin{array}{l}\text { Building } 2 \\
\text { Wall } 3\end{array}$ & Sub-sample & $\begin{array}{l}\text { Rammed earth wall } \\
\text { and reddish silty } \\
\text { clay surface }\end{array}$ & $\mu$-IR \\
\hline SA1799 & 10 & $\begin{array}{l}\text { Building } 8 \\
\text { Wall } 56\end{array}$ & Sub-sample & $\begin{array}{l}\text { Mud-brick wall, } \\
\text { multiple green, } \\
\text { grey, brown and } \\
\text { white plasters and } \\
\text { red pigment }\end{array}$ & $\begin{array}{c}\mu \text {-IR } \\
\text { ESEM-EDX }\end{array}$ \\
\hline SA1505 & 10 & $\begin{array}{l}\text { Building } 8 \\
\text { Space } 47\end{array}$ & Sub-sample & $\begin{array}{c}\text { Clay with red } \\
\text { pigment }\end{array}$ & IR \\
\hline SA1469 & 10 & $\begin{array}{l}\text { Building } 8 \\
\text { Space } 47 \\
\end{array}$ & Sub-sample & Red pigment & IR \\
\hline SA2308 & 10 & $\begin{array}{l}\text { Building 5 } \\
\text { Space 27 } \\
\text { (sounding) }\end{array}$ & Sub-sample & $\begin{array}{l}\text { Hard white sloping } \\
\text { surface in front of } \\
\text { entrance to } \\
\text { Building } 5\end{array}$ & IR \\
\hline $\begin{array}{l}\text { No sample } \\
\text { number }\end{array}$ & 10 & $\begin{array}{l}\text { Building } 5 \\
\text { Space 50 }\end{array}$ & Sub-sample & $\begin{array}{c}\text { Black pigment on } \\
\text { human skull }\end{array}$ & $\begin{array}{c}\mu-\mathrm{IR} \\
\text { ESEM-EDX }\end{array}$ \\
\hline
\end{tabular}

\section{Materials and Methods}

Large micromorphological thin sections of architectural materials, $14.5 \times 7 \mathrm{~cm}$, were produced at the University of Reading by impregnation with epoxy resin of block samples which had been removed from the site at Bestansur, with permission for scientific analysis. A $30 \mu \mathrm{m}$-thick cross-section was subsequently produced by cutting, mounting onto a glass slide support, grinding and polishing using an oil-cooled diamond-edge Brot grinder-polisher.

Spot sub-samples of archaeological deposits and materials were analysed as powders by ATR-IR using a PerkinElmer Spectrum 100 FT-IR spectrometer set to record between $4000-510 \mathrm{~cm}^{-1}$ at a resolution of $4 \mathrm{~cm}^{-1}$ with 16 repeat scans.

The large resin-impregnated thin-sections of intact sequences of architectural materials were first analysed by optical microscopy using a Leica DMEP Polarising Microscope. Photomicrographs were recorded using $a$ Leica DMEP DFC 290 camera. All of the images in this paper were recorded at a magnification of $x$ 40. Based on these optical microscopic examinations, specific components and materials were for micro-analysis using IR microscopy to examine the mineralogy and ESEM-EDX to determine elemental composition.

The mineralogy of regions of specific mineralogical interest in thin sections were analysed by $\mu$-IR using a Perkin-Elmer Spectrum 100 FT-IR spectrometer with a spotlight 400 imaging system attachment. Point spectra were recorded between $4000-500 \mathrm{~cm}^{-1}$ at a resolution of $2.00 \mathrm{~cm}^{-1}$ with 64 repeat scans and an aperture size of $100 \times 100 \mu \mathrm{m}$. IR maps were recorded between $4000-680 \mathrm{~cm}^{-1}$ at a resolution of $1.00 \mathrm{~cm}^{-1}$ with a pixel size of $25 \mu \mathrm{m}$ and 16 repeat scans per pixel. All spectra were recorded in reflectance mode as the IR beam is absorbed by the glass slide of the thin sections, preventing the use of transmittance mode. Due to the size of the thin sections, the lower Cassegrain of the spectrometer was removed prior to analysis.

Elemental analysis of areas of interest in the samples was performed using an FEI Quanta FEG 600 Low Vacuum Scanning Electron Microscope with an Oxford Instruments INCA X-Ray Analysis System. Samples were analysed in a low vacuum, eliminating the need for the application of gold-coating, which would have damaged the sample. Thin sections were attached to two large stubs with carbon pads to secure them to the stage.

Two experiments were carried out in which samples were subjected to heating in the laboratory as described below. These were: (i) heating of a sample of $\mathrm{CaCO}_{3}$, followed by cooling and the subsequent analysis of the sample over time, using IR spectroscopy to study the degradation of "fired lime"; (ii) heating of a sample of clay from Bestansur to monitor changes in the IR spectrum at different temperatures to look for evidence of burning.

\section{Results and Discussion}




\section{Trench 1, Building 2}

The aim of this experiment was to determine whether the reddish colouration of the silty clay surface of the rammed earth wall of Building 2 in thin section SA542, was due to post-depositional burning or oxidation using IR microscopy to monitor changes in the IR spectrum of clay at increasing temperatures.

Before analysis of the thin section was performed, an experiment was devised to investigate the effect on the IR absorption frequencies of heating of clay at $100{ }^{\circ} \mathrm{C}$ intervals. A small amount of a typical clay sample from trench 10, sub-sample SA1505, was used in this investigation with the intention of comparing the results obtained to those observed for the thin section SA542. Firstly an IR spectrum was recorded of the clay sample SA1505 before it was subjected to any heat. The observed IR frequencies are listed in Table 2.

Table 2- IR absorption frequencies of clay sample. (* Clay peaks are difficult to assign as often there is more than one type of clay present in the sample).

\begin{tabular}{|c|c|c|}
\hline Wavenumber $\mathbf{( c m}^{-\mathbf{1}} \mathbf{)}$ & Mineral & Peak Assignment* \\
\hline 3712 & Clay & $\mathrm{Al}-\mathrm{O}-\mathrm{H} / \mathrm{Si}-\mathrm{O}-\mathrm{H}$ \\
\hline 3626 & Clay & $\mathrm{Al}-\mathrm{O}-\mathrm{H} / \mathrm{Si}-\mathrm{O}-\mathrm{H}$ \\
\hline 3408 & Clay & $\mathrm{H}-\mathrm{O}-\mathrm{H}$ \\
\hline 1650 & Clay & $\mathrm{H}-\mathrm{H}$ \\
\hline 1432 & Calcite & $\mathrm{CO}_{3}{ }^{2-}$ asymmetric stretch \\
\hline 992 & Clay & $\mathrm{Si}_{-} \mathrm{O}-\mathrm{Si} / \mathrm{Si}-\mathrm{O}-\mathrm{Al}$ \\
\hline 874 & Calcite & $\mathrm{CO}_{3}{ }^{2-}$ bend \\
\hline 800 & Clay & $\mathrm{Si}^{-O}-\mathrm{O}$ \\
\hline 774 & Clay & $\mathrm{CO}_{3}{ }^{2-}$ bend \\
\hline 714 & Calcite & $\mathrm{Si}_{-} \mathrm{O}-\mathrm{Al}$ \\
\hline 686 & Clay & - \\
\hline 656 & Clay & $\mathrm{Si}_{-} \mathrm{O}-\mathrm{Al}$ \\
\hline 532 & Clay & \\
\hline
\end{tabular}

A small section of sample SA1505 was placed in a muffle furnace and heated slowly to $900{ }^{\circ} \mathrm{C}$. ATR-IR spectra were recorded at intervals of $100^{\circ} \mathrm{C}$ by removing a small amount of clay from the sample and grinding with a pestle and mortar. The experiment confirmed that the heating of clay results in changes in the IR spectrum, due to elimination of water, decomposition of carbonates and structural changes. Changes were seen at 500,800 and $900{ }^{\circ} \mathrm{C}$ in the IR spectrum in Figure 3 . 


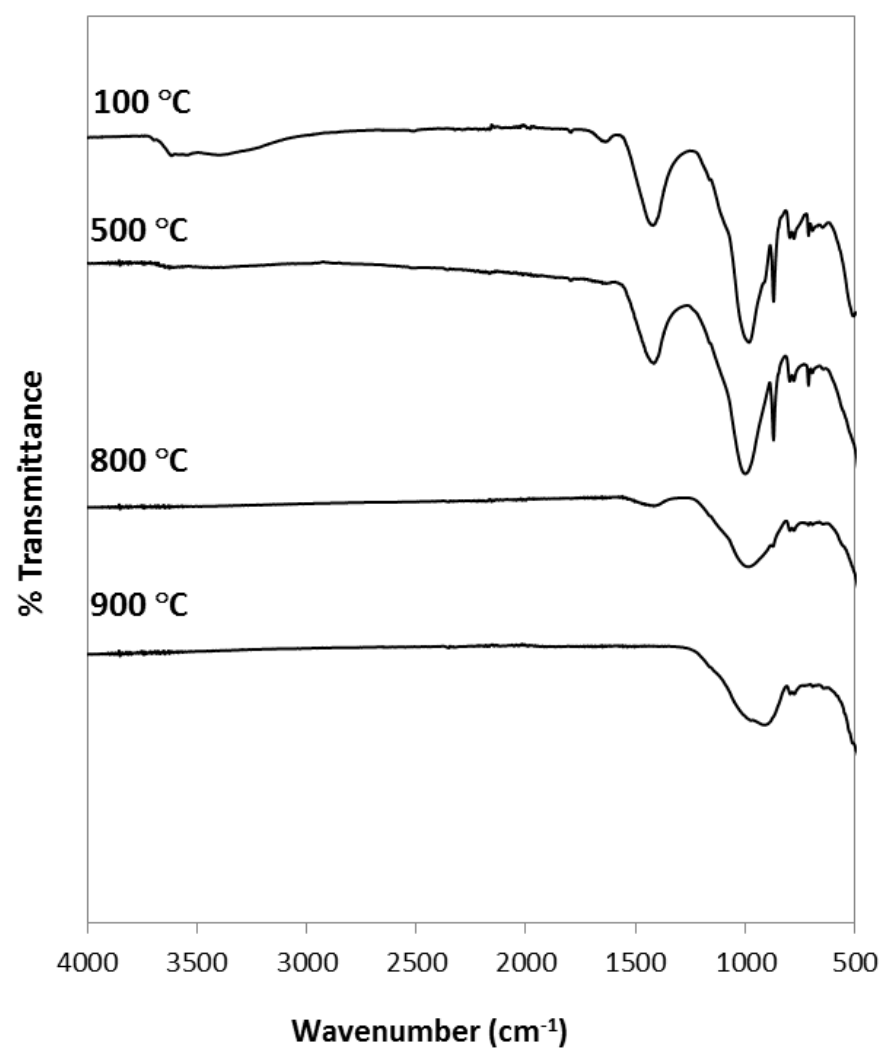

Figure 3- IR spectrum showing the effect of heating on IR absorption frequencies of a clay sample taken from a rammed earth mud wall of Building 2 (sample SA1505).

At $500{ }^{\circ} \mathrm{C}$ water within the structure was eliminated as indicated by the large decrease in the IR absorption peaks at $3712-3408 \mathrm{~cm}^{-1}$ and $1650 \mathrm{~cm}^{-1}$ which correspond to $v(\mathrm{O}-\mathrm{H})$ and $\delta(\mathrm{H}-\mathrm{O}-\mathrm{H})$ absorptions. Continued heating resulted in further changes that can be seen in Figure 4. The decomposition of calcite $\left(\mathrm{CaCO}_{3}\right)$ begins at $800{ }^{\circ} \mathrm{C}$, shown by a decrease of characteristic absorptions corresponding to the $\mathrm{CO}_{3}{ }^{2-}$ asymmetric stretch, outof-plane bend and in-plane bend at 1414,870 and $712 \mathrm{~cm}^{-1}$ respectively [19]. Full decomposition of calcite was seen at $900{ }^{\circ} \mathrm{C}$ with complete disappearance of calcite peaks. A change in the peak shape of the $\mathrm{Si}-\mathrm{O}-\mathrm{Si}$ absorption at $990 \mathrm{~cm}^{-1}$ was also observed at $900{ }^{\circ} \mathrm{C}$.

The decrease in absorption frequency of the $(v(\mathrm{Si}-\mathrm{O}))$ clay peak $[20,21]$ above $500{ }^{\circ} \mathrm{C}$ was also observed in a similar study by Forget et al. which showed a decrease in absorption frequency of $7 \mathrm{~cm}^{-1}$ upon heating from $500-800{ }^{\circ} \mathrm{C}$ as well as an increase in the bandwidth of the peak when the sample was heated above $700{ }^{\circ} \mathrm{C}$ [22].

The clay peaks in the current investigation also show an increase in bandwidth beginning markedly at $700{ }^{\circ} \mathrm{C}$, but becoming very noticeable at 800 and $900{ }^{\circ} \mathrm{C}$. In an investigation by Shoval et al. which determined the maximum burning temperature of clay at an Iron Age site in Israel, it was concluded that the broadening of the $\mathrm{Si}-\mathrm{O}-\mathrm{Si} / \mathrm{Si}-\mathrm{O}-\mathrm{Al}$ peak at temperatures of $700{ }^{\circ} \mathrm{C}$ upwards was indicative of the formation of glassy phases [23]. These occur following a structural change in the clay, which is also likely to have caused the change in peak shape at $900{ }^{\circ} \mathrm{C}$ observed in this investigation (Figure 4). 

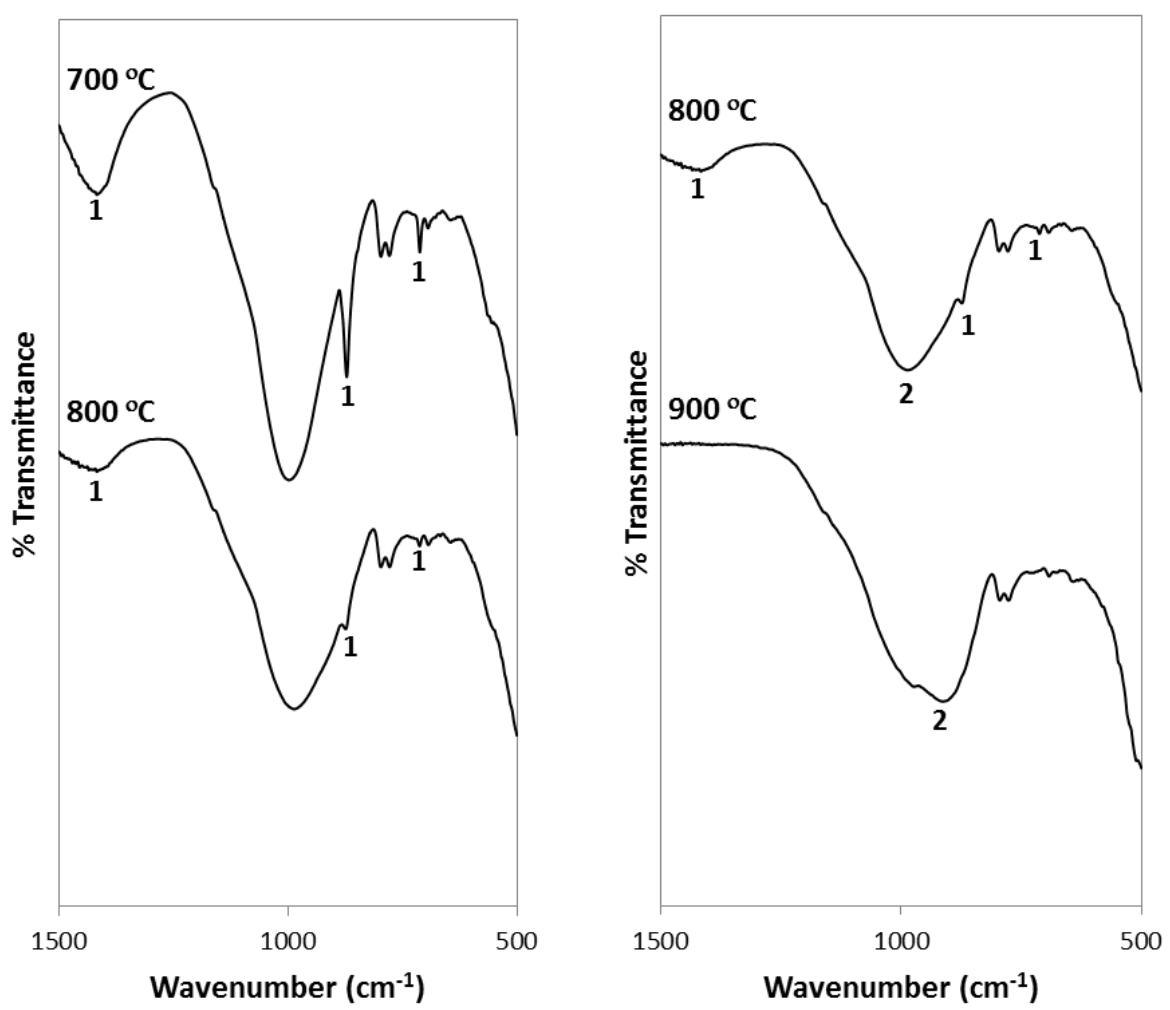

Figure 4- IR spectrum showing changes at 800 and $900^{\circ} \mathrm{C}:(1)=$ calcite, $(2)=$ clay of clay taken from a mud brick from building 2 (sample SA105).

The experiment determined that IR spectroscopy is a useful technique for the identification of burning in clay samples. The various changes observed as the temperature of burning increased indicates that this technique may also be used to elucidate the temperature of burning by looking for changes in the spectrum that occur at specific temperatures. For example, clays that do not display an absorption peak at $\sim 3700 \mathrm{~cm}^{-1}$ but do display calcite and silicate peaks are likely to have been subjected to temperatures between $500-700{ }^{\circ} \mathrm{C}$. Clays that show a decrease in the intensity of calcite peaks are likely to have been heated to $800{ }^{\circ} \mathrm{C}$ and clays showing a lack of calcite peaks are likely to have been heated up to or above $900{ }^{\circ} \mathrm{C}$.

However, caution should be employed in the use of IR absorption frequencies to determine the temperature of burning as different clays contain various specific clay minerals and different concentrations of calcite and other components which will not only result in different absorption frequencies but may also show decomposition or dehydration at different temperatures.

Following the investigation into the effects of heating on clay, $\mu$-IR was used in the analysis of the silty clay wall surface in thin section SA542 which was suspected to have been subjected to burning due to its partial reddish colouration. Although slight differences in peak shape of the IR absorption at $\sim 1010 \mathrm{~cm}^{-1}$ were observed for the different regions (lighter and darker-red) the spectra shown in Figure 5 indicate that neither the darker nor the lighter clay in this sample had been subjected to high temperatures. 


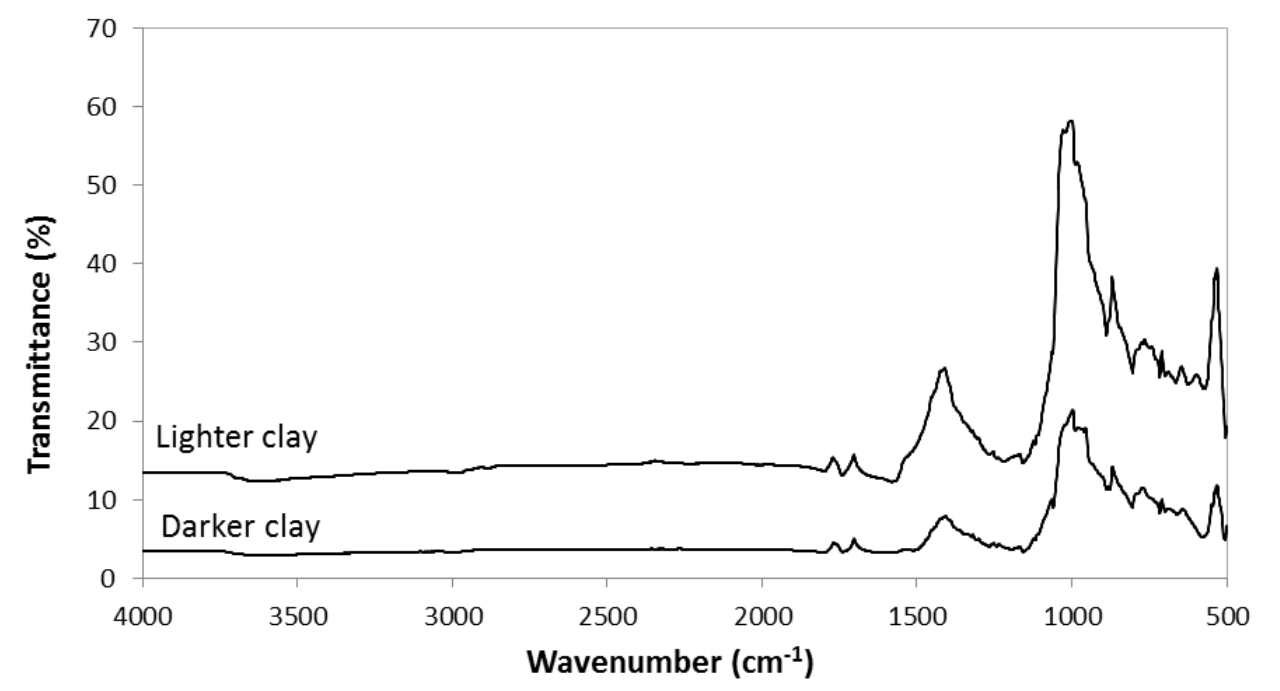

Figure 5- IR spectrum of possible unburnt (lighter) and burnt (darker) regions of clay from a mud brick from building 2 (sample SA542).

The spectra display both calcite and clay peaks, neither of which appears to show degradation, indicating that neither of the regions of clay had been subjected to temperatures over $700{ }^{\circ} \mathrm{C}$. Both clays also demonstrate broad absorption peaks at 3750-3470 $\mathrm{cm}^{-1}$ and therefore it can be concluded that they have not been heated to above $500{ }^{\circ} \mathrm{C}$ as water has not been eliminated from the structure. It was therefore determined that the red colouration previously thought to have been caused by burning is more likely to be the result of a bioturbation channel, which is the movement of minerals by earthworms or plant roots, which often disturb archaeological sites.

\section{Trench 10}

Several samples were analysed from Trench 10, which was excavated to a total area of $12 \times 9 \mathrm{~m}$, revealing a series of distinct buildings from superimposed phases of occupation of the site as can be seen in Figure 6 . The buildings in this trench were quite elaborate, with one (Building 8) displaying multiple layers of plasters of different colours and red and possibly black pigments and paint. Building 8 was dated as pre 7,600 BC and was constructed with dark-greyish-brown mud-bricks walls and mud mortar rendered by a sequence $3.4 \mathrm{~cm}$ thick of grey, green, brown and white silty clay plasters and washes and the use of red pigment in wall paintings later in the history of the building. The later stages of decoration in Building 8, with multiple thin layers of white wash were not dissimilar to the types of decoration found a Çatalhöyük, Turkey in previous studies by Anderson et al. at Reading discussed below [7]. Building 8 is the earliest Building level currently exposed by excavations in Trench 10.

Building 5 was constructed on top of Building 8 and is similar in plan, but had a larger main room, Space 50 and two narrow side rooms (Figure 6). It is one of the latest buildings in this trench to have been occupied, dated at 7,600 BC. However, although occupied at a more advanced date, there are fewer layers of green, grey and white plaster on the wall. The only traces of pigment on the walls of Building 5 are indistinct patches of red at the entrance into Space 50. This pigment, however, is likely to have held some significance as this entrance marks the passageway into a large room with $>28$ human burials, most below the floor. Traces of red pigment were found as fragments on floors in all of the rooms of Building 5 .

At the front of these buildings is a sloping open area that was surfaced early in its history with a hard slightly pale reddish white material, exposed in the excavation of small 'sounding' in Space 27. It was hypothesised that this hard whitish material might have been manufactured from fired lime $(\mathrm{CaO})$, which has been identified from other Neolithic sites of similar and earlier date [11,24].

Several samples from this trench were analysed. The description and location of these samples can be seen in Table 1. 


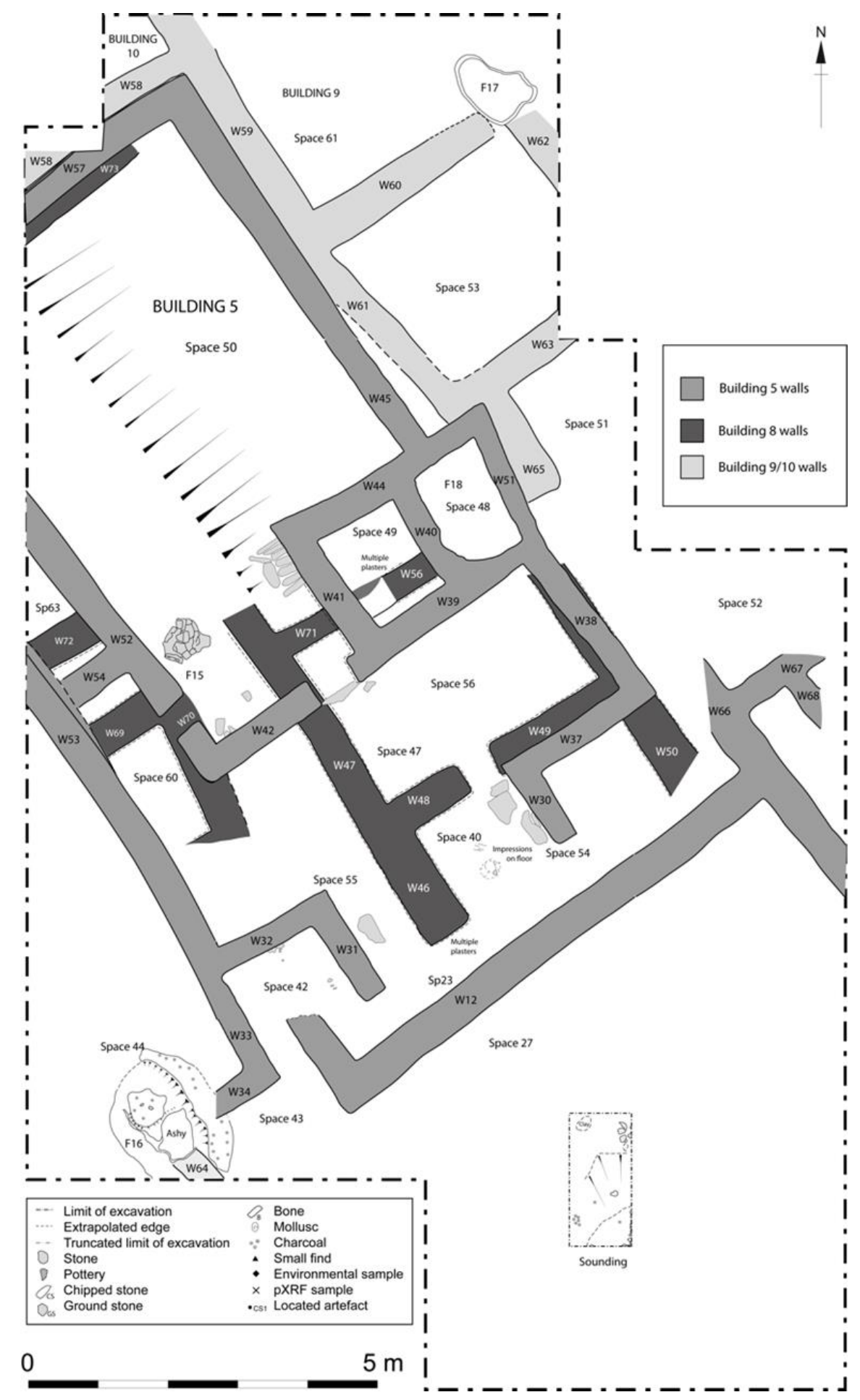

Figure 6- Plan showing the positions of Buildings 5 and 8 from which the samples whose analysis is described in this paper were taken. Building 5 is later than Building 8 and was constructed on top of it (see text). 


\section{Building 5}

\section{"Fired Lime" Samples}

In Figure 7 (sample SA2308) is shown an infrared spectrum of the hard thick white plaster taken from the sloping exterior surface in front of Building 5 and 8 in space 27. The spectrum shows peaks of $\mathrm{CaCO}_{3}$ at 1394 , 870 and $712 \mathrm{~cm}^{-1}$ [19] alongside peaks from a clay mineral, the most prominent of which is at $1014 \mathrm{~cm}^{-1}[20$, 21]. Is there any evidence that this sample has come from "fired lime" i.e. $\mathrm{CaCO}_{3}$ which has been fired to form $\mathrm{CaO}$ and then used as a lime surface. An experiment was carried out in which $\mathrm{CaCO}_{3}$ was heated to $900{ }^{\circ} \mathrm{C}$ and left to cool, recording infrared spectra of the sample at time periods of 30 minutes, 1 hour, 6 hours and 1 week. It is found that after 30 minutes a peak due to $\mathrm{Ca}(\mathrm{OH})_{2}(\mathrm{v}(\mathrm{OH}))$ appears at $3639 \mathrm{~cm}^{-1}$ and grows progressively throughout the 1 week period of the experiment. A second band - at $1402 \mathrm{~cm}^{-1}$ - appears after 1 hour of the experiment and again grows throughout the experiment. This band is assigned to the asymmetric stretch of the $\mathrm{CO}_{3}{ }^{2-}$ ion. The spectrum of this heated sample after being left for 41 days is shown in the lower spectrum of Figure 7 where it is compared with the spectrum of sample SA2308. If the clay mineral bands in sample SA2308 are ignored there is a good match between the bands seen for this sample and that of the fired lime from our experiment. However, unfired $\mathrm{CaCO}_{3}$ shows very similar IR absorptions. Thus our experiment lends support to the hypothesis that sample SA2308 is formed of fired lime mixed with a clay mineral but it cannot unequivocally prove this theory.

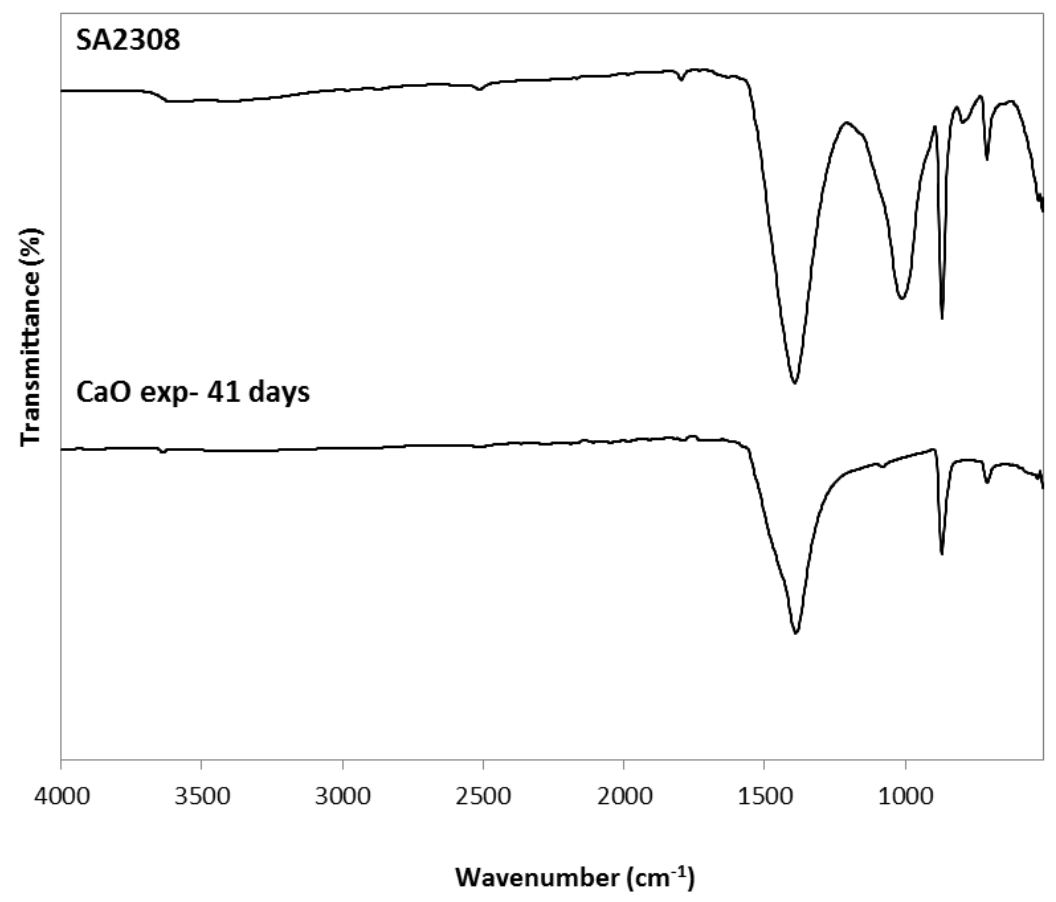

Figure 7- Infrared spectrum of plaster taken from Building 5 (sample SA2308) and suspected to be formed of "fired lime". Stretching and bending modes of the carbonate ion in CaCO3 can clearly be seen at 1394, 870 and $712 \mathrm{~cm}^{-1}$.

\section{Red Pigments}

A sub-sample of red pigment recovered from space 47 in building 5 (sample SA1469) was analysed using IR. As discussed previously, ochres are natural earth pigments with an iron oxide chromophore. Several types of iron oxide occur naturally, however it is known that hematite is a common Neolithic pigment which has been detected at other archaeological sites by infrared spectrometry [6, 25, 26]. Sample SA1469 was analysed using $\mu$-IR and compared to a sample of clay (SA1505). Sample SA1469 was found to contain both clay and calcite. The main difference observed between the red ochre (SA1469) and the clay spectrum was an increase in the concentration of calcite for the red ochre. The IR spectrum did not demonstrate any absorption peaks for hematite despite the expectation of observing a peak at around $550 \mathrm{~cm}^{-1}$. It is likely that hematite is present, but 
the low concentration of iron oxide was not detected perhaps due to the large concentration of clay which displays a fairly broad absorption peak at $530 \mathrm{~cm}^{-1}$ which would overlap with the lower intensity proposed peak for hematite. The spectrum produced resembles that seen in the work of Mortimore et al. in previous studies at Reading [25]. Further peaks for hematite would have been observed at $480-450 \mathrm{~cm}^{-1}$ and $352-310 \mathrm{~cm}^{-1}$ however, the instrument used, despite having a wavenumber range of 4000-400 $\mathrm{cm}^{-1}$ was limited to measurements of frequencies above $500 \mathrm{~cm}^{-1}$ as below this frequency, the signal to noise ratio was very poor. Despite the inconclusive analysis using IR spectroscopy, it remains likely that the sample contains hematite. Analysis of red pigments in the thin section SA1799 from building 8 further justified this conclusion, as will be discussed later.

\section{Building 8}

\section{Green, Grey and White Plasters}

A block sample (SA1505) was extracted from wall 56 of building 8 (see Figure 6) and a thin section of this was produced to study the sequence of plaster layers. An infrared spectroscopic investigation was undertaken of the green, grey and white plaster layers from this section (see Figure 8). The first question to address is: what is the nature and source of the green plaster layers in the earliest sequences. It had been proposed that these may have been formed from the mineral glauconite- $(\mathrm{K}, \mathrm{Na})\left(\mathrm{Fe}{ }^{\mathrm{III}}, \mathrm{Al}, \mathrm{Mg}\right)_{2}(\mathrm{Si}, \mathrm{Al})_{4} \mathrm{O}_{10}(\mathrm{OH})_{2}$ as soft green rock fragments were excavated at the site in Bestansur and were identified preliminarily as glauconite. Infrared spectra showed peaks in the region $1000-1100 \mathrm{~cm}^{-1}$ which could arise from $v(\mathrm{Si}-\mathrm{O})$ or $v(\mathrm{Al}-\mathrm{O})$ vibrations but cannot definitively characterise the sample as glauconite. As such SEM-EDX was carried out, giving the following elemental atomic ratios ( $\mathrm{Si}$ set to 100): $\mathrm{Si}, 100 ; \mathrm{Ca}, 40 ; \mathrm{Al}, 32 ; \mathrm{Fe}, 11 ; \mathrm{Mg}, 12 ; \mathrm{K}, 6$. The lack of sodium in the mineral shows that it cannot be glauconite [26] while the presence of potassium precludes it being a form of chlorite another relatively common green mineral - which occurs in many forms [27] but with the general formula $(\mathrm{Al}, \mathrm{Mg}, \mathrm{Fe})_{6}(\mathrm{Si}, \mathrm{Al})_{4} \mathrm{O}_{10}(\mathrm{OH})_{8}$. The most likely candidate for the green mineral is therefore celadonite, $\mathrm{K}\left(\mathrm{Mg}, \mathrm{Fe}^{\mathrm{II}}\right)\left(\mathrm{Fe}^{\mathrm{III}} \mathrm{Al}\right)\left(\mathrm{Si}_{4} \mathrm{O}_{10}\right)(\mathrm{OH})_{2}$ which has been detected at separate archaeological sites in Egypt and India $[26,28]$. Although the site at Bestansur largely significantly predates these sites, the use of celadonite at these sites appears to have been both structurally and decoratively appealing. Celadonite shows infrared absorbances at 1018 and $1074 \mathrm{~cm}^{-1}$ [29] which matches the observed infrared spectrum of broad peaks around 1000-1100 $\mathrm{cm}^{-1}$. Celadonite is a likely component of the geology around Bestansur being a type of marine clay which could have been deposited when the Central Zagros region lay below the Tethys Sea in the Jurassic period [30].

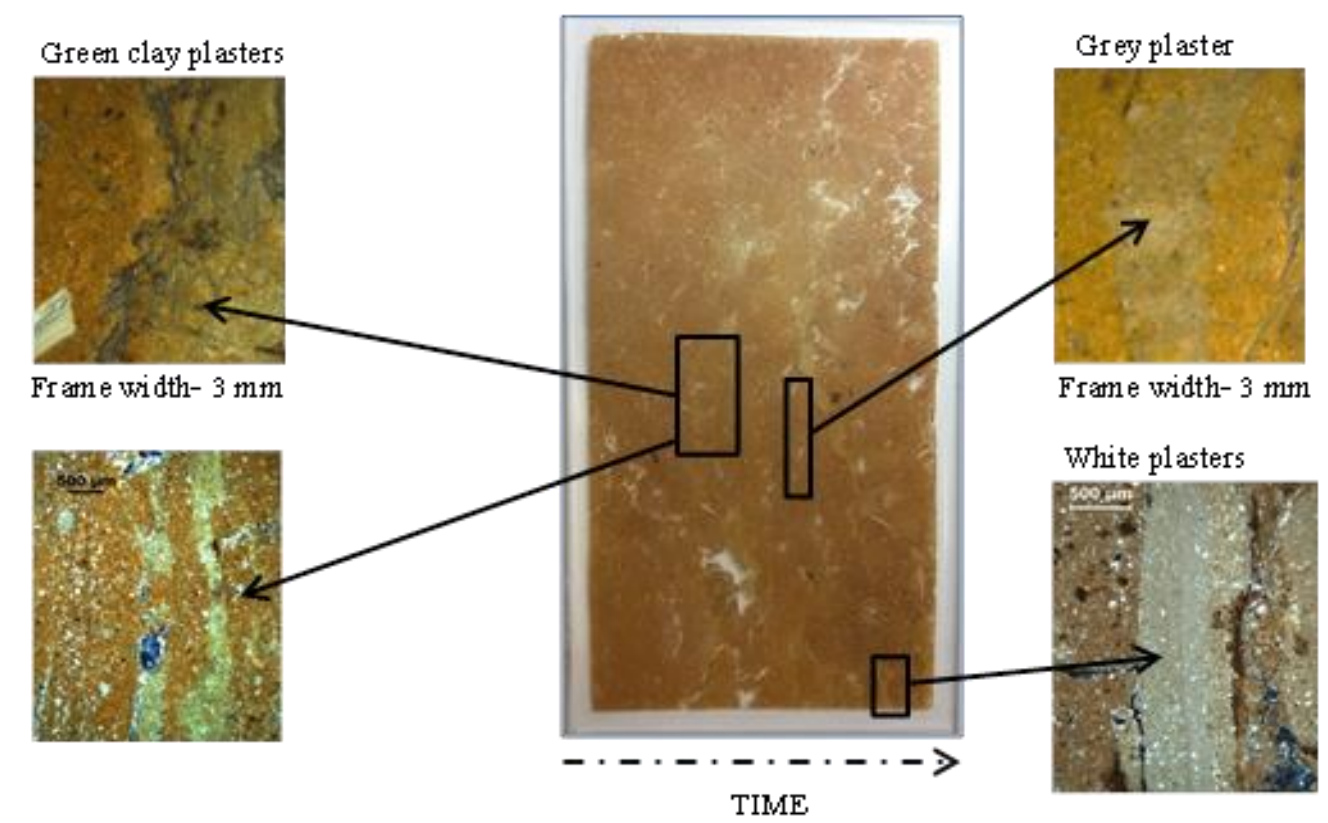

Figure 8- Diagram showing position of features in this section of plaster layers from Building 8 (sample SA1505). The earliest sequences of plasters are to the left of the section. 
The next plaster layer in the sequence to be investigated was a grey plaster which precedes a much whiter plaster seen at the end of the sequence. The grey plaster is discontinuous due to bioturbation, however, it is clearly observed as a definite plaster layer. A point spectrum was recorded using the IR microscope which displayed absorption peaks of both calcite and clay. In comparison to the white plaster layer which follows this layer, a larger ratio of clay to calcite was observed which is likely to cause the off-white colouring observed in this plaster layer. The point spectra of the grey and white plasters can be seen in Figure 9 which demonstrates clearly the different concentrations of clay $\left(v 1000 \mathrm{~cm}^{-1}\right)$ and calcite $\left(v 1420 \mathrm{~cm}^{-1}\right)$.

A sequence of white plaster washes was also observed in optical microscopic analyses. The IR spectrum shown in Figure 9 demonstrates that this later sequence of plasters contains a much higher concentration of calcite. A series of chemimaps were therefore produced by $\mu$-IR to map concentrations of (i) calcite, (ii) clay minerals and (iii) quartz and these are illustrated in Figure 10. It is seen that a series of layers exist and that the paler layers contain a higher concentration of calcite but a lower concentration of clay and quartz. This finding was supported by ESEM-EDX in which the concentrations of $\mathrm{Ca}$ and $\mathrm{Si}$ were mapped. In this case the $\mu$-IR experiment gave a much clearer definition of the individual plaster layers.

There is an apparent progression in technologies from the previous clay rich plaster layers to the multiple fine white plaster layers. The plaster layer sequences begin with a green clay which was most likely applied as found at the source, which is then followed by a calcite and clay plaster, which was likely to have been mixed either to preserve the sources of the more favourable calcite or to bind the plaster more effectively. The final sequence in the thin section comprises clear foundation and finishing plasters, with an obvious preference for the brighter white calcite plaster in this important building.
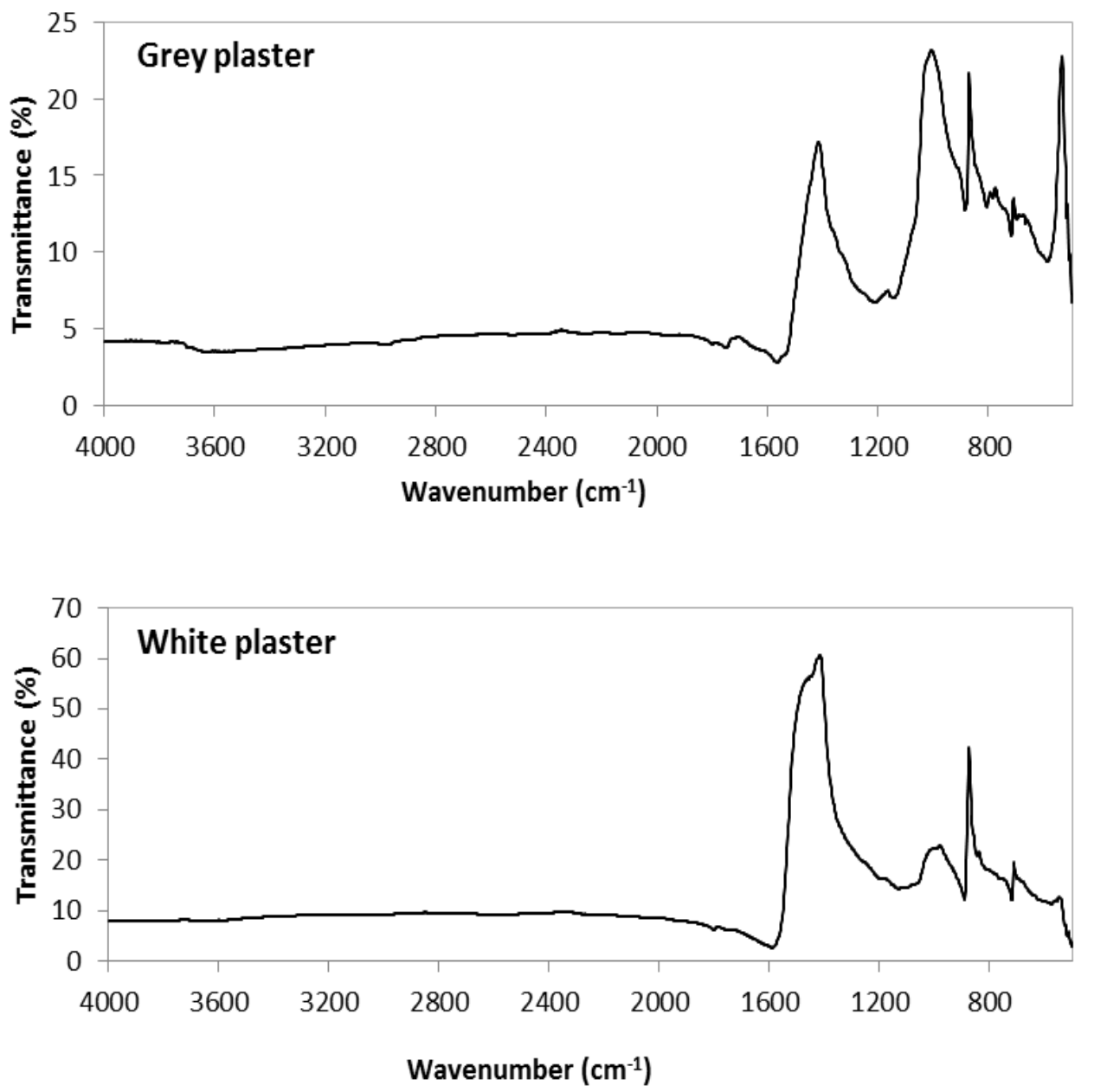

Figure 9- Infrared spectra of Grey and White Plasters taken from thin section SA1799 from Building 8. 

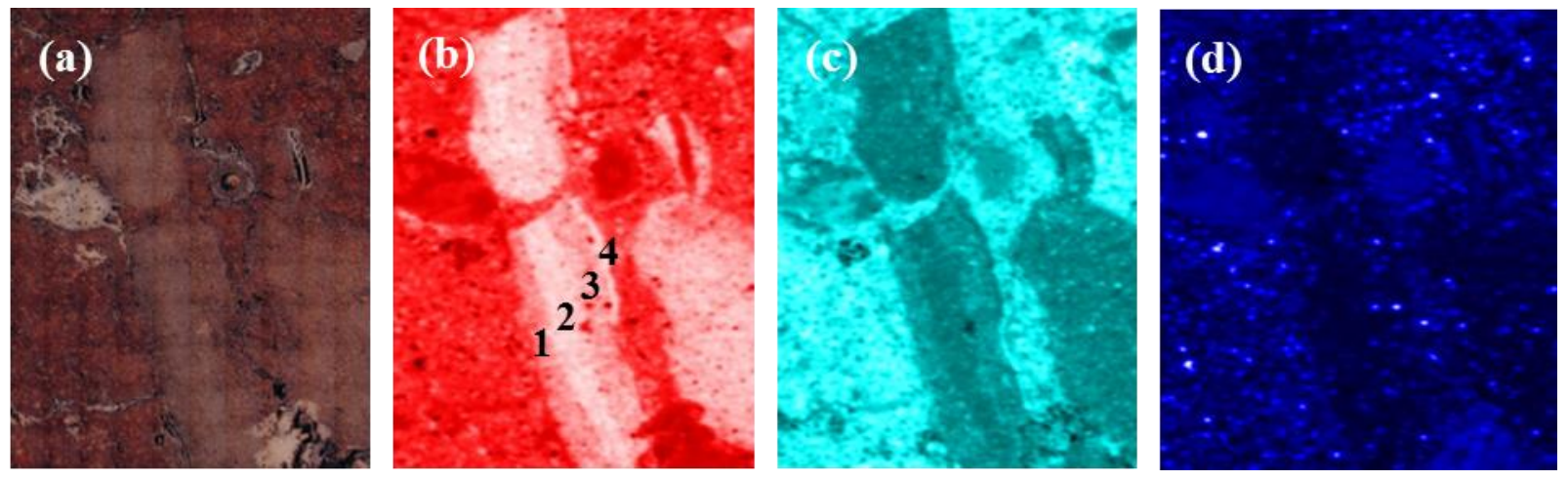

Figure 10- Chemimaps produced from $\mu$-IR mapping experiment showing (a) visible image of region, (b) location of calcite, showing distinct layers, (c) location of clay and (d) location of quartz (From Sample SA1505).

\section{Red Pigment from Wall Decoration}

The multiple wall plasters in Building 8 also demonstrated red pigment (sample SA1799) both before and after the white plaster layers. These areas of pigmentation were analysed by $\mu$-IR and ESEM-EDX. The red pigment is thought to be part of a wall painting because it is discontinuous along the plaster layers; an overall layer of surface paint would have shown up as a continuous layer. The design of the painting is not yet known as Building 8 has only been partially excavated below building 5 . $\mu$-IR showed peaks due to $\mathrm{CaCO}_{3}$ at 1424,870 and $712 \mathrm{~cm}^{-1}$ and of clay minerals at 982, 796,776, 672, 648 and $530 \mathrm{~cm}^{-1}$. There was no sign of hematite, $\mathrm{Fe}_{2} \mathrm{O}_{3}$, which is a likely red pigment used at Neolithic sites [21, 31]. ESEM-EDX gives the following elemental ratios with $\mathrm{Si}$ being set to 100: $\mathrm{Si}, 100 ; \mathrm{Ca}, 46 ; \mathrm{Al}, 43 ; \mathrm{Mg}, 16 ; \mathrm{Fe}, 10 ; \mathrm{K}$, 7. Although not 100\% conclusive the relatively high concentration of iron found in this red pigment suggests strongly that the pigment is indeed hematite. The other elemental concentrations may be explained by the presence of $\mathrm{CaCO}_{3}$ with some $\mathrm{Ca}^{2+}$ ions replaced by $\mathrm{Mg}^{2+}$ and clay minerals containing $\mathrm{Si}, \mathrm{Al}$ and $\mathrm{K}$.

\section{Black Substance from Human Skull}

In Figure 11 is shown a small fragment of human skull excavated from building 5 and showing an area of black pigmentation. A sample of this pigmented area was analysed by IR microspectroscopy. Peaks were seen at $1400,1022,860,600$ and $560 \mathrm{~cm}^{-1}$ which are assigned to stretching and bending modes of phosphate (1022, $600,560)$ and carbonate $\left(1400\right.$ and $\left.860 \mathrm{~cm}^{-1}\right)$ ions. This finding is entirely indicative of bone, showing peaks of calcium phosphate substituted by some carbonate ions [32, 33].

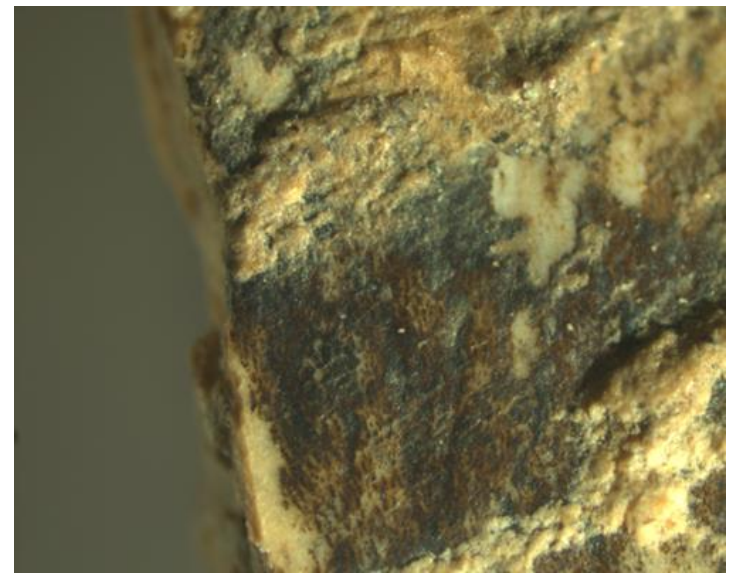

Figure 11- Fragment of human skull taken from Building 5 showing black deposit which was analysed in this research.

The infrared spectrum did not, however, give any clue as to the nature of the black residue. As such this material was subjected to elemental analysis by ESEM-EDX. This showed the following elements in the following 
atomic ratios (with $\mathrm{Si}$ set to 100 ): $\mathrm{Si}, 100 ; \mathrm{Ca}, 59 ; \mathrm{Al}, 45 ; \mathrm{Mn}, 31 ; \mathrm{Mg}, 19 ; \mathrm{Fe}, 15 ; \mathrm{K}$, 10. This suggests that the dark black pigment is $\mathrm{MnO}_{2}$ with an iron oxide - possible magnetite $\mathrm{Fe}_{3} \mathrm{O}_{4}$ (which is dark brown in colour). It is known that $\mathrm{MnO}_{2}$ and $\mathrm{Fe}_{3} \mathrm{O}_{4}$ are formed by $\mathrm{Mn}$ - and Fe-oxidising bacteria within the soil [34, 35]. Hence it is likely that the black pigmentation on the skull is formed in a post-depositional event and discounts the possibility that the coloration was applied to the skull by humans in Neolithic times.

\section{Conclusions}

IR spectroscopy is a sensitive, non-destructive technique which also benefits from relatively simple sample preparation. It can be used to assign the mineralogical composition of a sample as opposed to solely determine the elemental composition. However, it remains a rather underused technique in scientific archaeology. Its use, however, is becoming more widespread as may be seen from the following examples.

In 2012, Aquilia et al. used Fourier Transform Infrared (FT-IR) spectroscopy amongst other techniques to successfully characterise blue, red and yellow painted plaster samples from Hellenistic paintings excavated in Sicily, Italy [36]. The blue, red and yellow pigments were determined to be Egyptian blue $\left(\mathrm{CuCaSi}_{4} \mathrm{O}_{10}\right)$, hematite $\left(\mathrm{Fe}_{2} \mathrm{O}_{3}\right)$ and goethite $(\mathrm{FeO}(\mathrm{OH}))$, respectively. The group also successfully characterised the plaster beneath the painting using FT-IR. It was found to be composed of calcite, which is the most common component of lime plasters and demonstrated characteristic peaks at 1430, 870 and $712 \mathrm{~cm}^{-1}$ [37]. The mineralogical composition of the plaster and pigments was determined in this case by comparison of the experimental spectra to a pre-existing IR database. Although this approach was effective in this case, we would recommend caution in utilising IR databases for the assignment of IR bands in mineralogical samples as each IR spectrum produced is individual and subject to slight shifts in peak position and differences in peak shape.

The use of FT-IR in archaeological plaster analysis has also been successful in the work of Baraldi et al. where the group determined the mineralogical composition of Roman age plasters excavated at a site in Northern Italy. The results confirmed the presence of calcite and silica and the absence of any organic components which would have been used to bind the plaster [38]. In a separate investigation by Mahmoud et al. analysis of plasters excavated in Egypt lead to similar findings. The plasters were determined to be composed of predominantly calcite with the presence of silicates also observed in the FT-IR spectrum [39]. On the other hand, Regev et al. found distinct results when investigating Iron Age plasters in Israel. The plasters were found to be composed of mainly silicates, with a smaller concentration of calcite. The IR spectrum produced was characteristic of hydraulic plaster which is prepared by mixing slaked lime $\left(\mathrm{Ca}(\mathrm{OH})_{2}\right)$ with disordered silicates (pozzolana) [38]. The characteristic IR absorption peaks of calcite at 1436, 874 and $712 \mathrm{~cm}^{-1}$ were observed for the plasters investigated by Aquilia, Baraldi and Mahmoud [36, 38, 39]. However, the plaster investigated by Regev et al. gave rise to a spectrum which showed a clear mixture of predominately disordered silicates with a broad absorption at $1036 \mathrm{~cm}^{-1}$ as well as the presence of calcite, confirming that the plaster is a typical hydraulic plaster.

The work described in the current paper extends the use of IR spectroscopy to a number of samples from the important early Neolithic site of Bestansur. Our work shows that in many cases the most compelling results are obtained when $\mu$-IR is combined with ESEM-EDX. $\mu$-IR provides information on the chemical or mineralogical nature of the material while ESEM-EDX gives the elemental concentrations.

Evidence was provided in this work that the rammed earth mud wall (SA542) from Building 2 at Bestansur had not been subjected to burning and that the white plasters found in Buildings 5 and 8 may come from "fired lime". The nature of green, grey and white plasters from Building 8 has been identified. The plaster layer sequences begin with a green clay which was most likely applied as found at the source, which is then followed by a pale grey calcite and clay plaster, which may have been mixed either to preserve the sources of the more favourable calcite or to bind the plaster more effectively. The final sequence in the thin section boasts foundation and finishing plasters, with an obvious preference for the brighter white calcite plaster in this important building.

The sequences of foundation and finishing plasters from building 8 (pre-7,600 BC) resemble those observed at a significantly later site in Çatalhöyük in Turkey which was occupied from 7, 100 BC. This discovery is important as it displays the early date of advanced technologies used at Bestansur. The use of fine white plasters at Bestansur also highlights a clear preference for the bright white plasters similar to those excavated at Çatalhöyük, which also boasted white finishing plasters. However, the calcite used at Bestansur is likely to have been sourced locally whereas the fine, bright white plasters excavated at Çatalhöyük were composed of dolomite sourced from around $6 \mathrm{~km}$ away, possibly indicating an established network around the site. The 
source of white clays in the Bestansur region is currently being investigated, but is reported to come from within the local region.

A red pigment used in an unexcavated wall-painting before and after the white plaster sequence in Building 8 was confirmed as hematite, $\mathrm{Fe}_{2} \mathrm{O}_{3}$. As mentioned previously, hematite was commonly used as a red pigment in Neolithic times. This pigment was shown by IR spectroscopy to contain no organic binders. Its location on top of the plaster layer and the absence of binders allows the conclusion that the pigment would have been applied using the 'fresco technique' which involved the application of pigment suspended in water to wet plaster $\mathrm{Ca}(\mathrm{OH})_{2}$. The plaster would then be left to dry forming $\mathrm{CaCO}_{3}$ which would fix the pigment in place.

A black substance found on a human skull from the same building almost certainly occurs from a mixture of the oxides $\mathrm{MnO}_{2}$ and $\mathrm{Fe}_{3} \mathrm{O}_{4}$. This mixture is likely to have been formed by microbial action [34, 35] and is therefore almost certainly post-depositional.

\section{Acknowledgements}

We wish to thank the many individuals and institutions who have kindly supported this research including: the Sulaimaniyah and Erbil Directorates of Antiquities and Heritage, State Board of Antiquities and Heritage, Baghdad, Iran's Cultural Heritage, Handicrafts and Tourism Organisation, the Iranian Centre for Archaeological Research and the Directorate General of Antiquities and Heritage, Turkey, their permission to export samples for scientific analysis; CZAP Co-Directors Prof Roger Matthews, Dr Yahgoub Mohammadifar and Kamal Rashid Raheem and team members, as well as the Sulaimaniyah Directorate of Antiquities and Heritage representative, Kamal Raouf; the Çatalhöyük Research Project and its Director Prof Ian Hodder, Shahina Farid and team members; Arts and Humanities Research Council (AHRC) UK (AH/H034315/1); University of Reading for the use of its Chemical Analysis Facility, Bu Ali Sina University, UCL; John Jack for manufacture of thin-sections, Amanpreet Kaur for help with ESEM-EDX analysis and Sarah Lucas and Dr Amy Richardson for the illustrations.

1 Damiani, D., Gliozzo, E., Memmi Turbanti, I., Spangenberg, J.E. (2003) Pigments and plasters discovered in the house of Diana (COSA, Grosseto, Italy): an integrated study between art history, archaeology and scientific analyses, Archaeometry, 45, 341-354.

2 Duran, A., Jimenez De Haro, M.C., Perez-Rodriguez, J.L., Franquelo, M.L., Herrera, L.K., Justo, A. (2010) DETERMINATION OF PIGMENTS AND BINDERS IN POMPEIAN WALL PAINTINGS USING SYNCHROTRON RADIATION - HIGH-RESOLUTION X-RAY POWDER DIFFRACTION AND CONVENTIONAL SPECTROSCOPY - CHROMATOGRAPHY, Archaeometry, 52, 286-307.

3 Gliozzo, E., Cavari, F., Damiani, D., Memmi, I. (2012) PIGMENTS AND PLASTERS FROM THE ROMAN SETTLEMENT OF THAMUSIDA (RABAT, MOROCCO), Archaeometry, 54, 278-293.

4 Miriello, D., Barca, D., Crisci, G.M., Barba, L., Blancas, J., Ortíz, A., Pecci, A., Luján, L.L. (2011) CHARACTERIZATION AND PROVENANCE OF LIME PLASTERS FROM THE TEMPLO MAYOR OF TENOCHTITLAN (MEXICO CITY), Archaeometry, 53, 1119-1141.

5 Miriello, D., Barca, D., Pecci, A., De Luca, R., Crisci, G.M., López Luján, L., Barba, L. (2015) Plasters from Different Buildings of the Sacred Precinct of Tenochtitlan (Mexico City): Characterization And Provenance, Archaeometry, 57, 100-127.

6 Anderson, E., Almond, M.J., Matthews, W., Cinque, G., Frogley, M.D. (2014) Analysis of Red Pigments from the Neolithic sites of Çatalhöyük in Turkey and Sheikh-e Abad in Iran, Spectrochimica Acta Part A: Molecular and Biomolecular Spectroscopy, 131, 373-383.

7 Anderson, E., Almond, M. J. and Matthews, W. (2014) Analysis of Wall Plasters and Natural Sediments from the Neolithic town of Çatalhöyük (Turkey) by a range of Analytical Techniques, Spectrochimica Acta - Part A Molecular and Biomoecular Spectrosopy, 133, 326-334.

8 Regev, L., Zukerman, A., Hitchcock, L., Maeir, A.M., Weiner, S., Boaretto, E. (2010) Iron Age hydraulic plaster from Tell es-Safi/Gath, Israel, Journal of Archaeological Science, 37, 3000-3009.

9 Regev, L., Poduska, K.M., Addadi, L., Weiner, S., Boaretto, E. (2010) Distinguishing between calcites formed by different mechanisms using infrared spectrometry: archaeological applications, Journal of Archaeological Science, 37, 3022-3029.

10 Weiner, S. (2010) Microarchaeology: Beyond the Visible Archaeological Record, Cambridge University Press, Cambridge.

11 Matthews, W., Almond, M.J., Anderson, E., Wiles, J., Williams, H. and Rowe, J. (2013)

Biographies of architectural materials and buildings: integrating new high-resolution micro- 
analysis and geochemistry. In Hodder I. (ed.) Substantive Technologies at Çatalhöyük: Reports from the 2000-2008 Seasons. Los Angeles: Costen Institute of Archaeology Press and British Institute at Ankara, 115-136.

Zeder, M. (2009) The Neolithic Macro-(R)evolution: Macroevolutionary theory and the study of culture change, Journal of Archaeological Research, 17, 1-63.

13 Braidwood, L., Braidwood, R., Howe, B., Reed, C., Watson, P.J. (1983) Prehistoric Archaeology Along the Zagros Flanks, The University of Chicago Oriental Institute, Chicago. Hole, F., Flannery, K.V., Neely, J.A. (1969) Prehistory and Human Ecology of the Deh Luran Plain: An Early Village Sequence from Khuzistan, Iran, University of Michegan, Ann Abor. Smith, P.E.L. (1990) Architectural innovation and experimentation at Ganj Dareh, Iran, World Archaeology, 21, 323-335. Matthews, R., Fazeli, H. (2013) The Neolithisiation of Iran: The formation of new societies, Oxbow Books, Oxford.

Matthews, R., Matthews, W., Raheem, K. R., Mohammadifar, Y., Aziz, K. R., Motarjem, A., Bendrey, R., Richardson, A., Elliott, S., Whitlam, J., Iversen, I., Charles, M., Bogaard, A., Mudd, D. and Walsh, S. In press. LONG-TERM HUMAN-ENVIRONMENT INTERACTIONS IN THE NEOLITHIC OF THE CENTRAL ZAGROS OF IRAN AND IRAQ, 10,000-6000 BC. In: Eidem, J. Ed., The Netherlands Institute for the Near East-75-Jubilee Conference "ZAGROS". NINO, Leiden. Farmer, V. C., (1974) The Infrared Spectra of Minerals, Mineralogical Society, London.

Saika, B. J., Parthasarathy, G. (2010) Fourier Transform Infrared Spectroscopic Characterisation of Kaolinite from Assam and Meghalaya, Northeastern India, Journal of Modern Physics, 1, 206210.

Van der Marel, H. W., Beutelspacher, H. (1976) Atlas of Infrared Spectroscopy of Clay Minerals and their Admixtures, Elsevier Scientific Publishing Company, Oxford.

Forget, M. C. L., Regev, L., Friesem, D. E. and Shahack-Gross, R. (2015) Physical and Mineralogical Properties of experimentally heated chaff-tempered mud bricks: implications for reconstruction of environmental factors influencing the appearance of mud bricks in archaeological conflagration events, Journal of Archaeological Scence Reports, 2, 80-93.

Shoval, S., Erez, Z., Kirsh, Y., Deutsch, Y., Kochavi, M. and Yadin, E. (1989) Determination of the intensity of an early iron age conflagration at Tel-Hadar, Israel, Thermochimica Acta, 148, 485-492.

Garfinkel, Y. (1987) Burnt lime products and social implications in the pre-pottery Neolithic B villages of the Near East, Paléorient, 13, 69-76.

Mortimore, J. L.,Marshall, L. J. R., Almond, M. J., Hollins P., and Matthews W. (2004) Analysis of red and yellow ochre samples from Clearwell caves and Çatalhöyük by vibrational spectroscopy and other techniques, Spectrochimica Acta - Part A Molecular and Biomolecular Spectroscopy, 60, 1179-1188.

Singh, M., Arbad, B. R. (2015) Characterisation of $4^{\text {th }}$ and $5^{\text {th }}$ century A. D. earthen plaster support layers of Ajanta mural paintings, Construction and building materials, 82, 142-154. Friedman, H. (2015). The Chlorite Mineral Group. http://www.minerals.net/mineral/chlorite.aspx Mahmoud, H. M., Kantiranis, N. and Stratis, J. (2012) A technical characterization of Roman plasters, Luxor Temple, Upper Egypt. Mediterranean Archaeology and Archaeometry, 12, 81-93. Salvadó, N., Butí, S., Tobin, M. J., Pantos, E., Prag, A. J. N. W. and Pradell, T. (2005) Advantages of the use of SR-FT-IR Microspectroscopy: Applications to Cultural Heritage, Analytical Chemistry, 77, 3444-3451.

30 Encyclopaedia Britannica, Inc. (2015). Tethys Sea. http://www.britannica.com/EBchecked/topic/588887/Tethys-Sea

31 Russell, J. D., Fraser, A. R., (1994) Infrared Methods, in: Wilson, M. J. (Ed.) Clay Mineralogy: Spectroscopic and Chemical Determination Methods, Chapman and Hall, London, pp 11-67. Edition, Wiley Interscience, New York.

Allen, S. D. M., Almond, M. J., Bell, M.G., Hollins. P., Marks, S. and Mortimore, J. L., (2002) Infrared Spectroscopy of the Mineralogy of Coprolites from Brean Down: evidence of past human activities and animal husbandry, Spectrochimica Acta - Part A Molecular and Biomoecular Spectrosopy, 58, 959-965. 
Faßbinder, J. W. E and Stanjek, H. (1993) Occurrence of bacterial magnetite in soils from archaeological sites, Archaeologia Polona, 31, 117-128.

36 Aquilia, E., Barone, G., Crupi, V., Longo, F., Majolino, D., Mazzoleni P. and Venuti, V.(2012) Spectroscopic Analyses of Hellenistic painted plasters from $2^{\text {nd }}$ century B.C., Sicily (South Italy), Journal of Cultural Heritage, 13, 229-233.

37 Regev, L., Zukerman, A., Hitchcock, L., Maeir, A.M.,Weiner, S. and Boaretto, E. (2010) Iron Age hydraulic plaster from Tell es-Safi/Gath, Israel, Journal of Archaeoogical. Science, 37, 30003009.

38 Baraldi, P., Bonazzi, A., Giordani, N., Paccagnella, F. and Zannini, P. (2006) Analytical Characterization of Roman plasters of the 'Domus Farini' in Modena, Archaeometry, 2006, 48, 481-499.

39 Marey Mahmoud, H.H., Ali, M.F., Pavlidou, E., Kantiranis, N. and El-Badry, A. (2011) Characterization of plasters from Ptolemaic baths: New excavations near the Karnak Temple complex, Upper Egypt, Archaeometry, 2011, 53, 693-706. 